\title{
MODERNIZATION OF THE MECHANISM FOR FINANCING RURAL DEVELOPMENT IN UKRAINE
}

\author{
Svitlana Yehorycheva ${ }^{1}$, Doctor of Economics/Professor; Tetiana Hudz ${ }^{2}$, Doctor of \\ Economics/Associate Professor and Mykola Lakhyzha ${ }^{3}$, Doctor of Public Administration/Professor \\ ${ }^{1}$ National University "Yuri Kondratyuk Poltava Polytechnic"; ${ }^{2}$ Poltava University of Economics and Trade; \\ ${ }^{3}$ Institute for Personal Training of the State Employment Service of Ukraine
}

\begin{abstract}
Rural areas occupy the major part of the territory of Ukraine, but they are characterized by low levels of socio-economic development, limitations in the amount and quality of public services, negative demographic trends. The aim of the article is to systematize modern means of financing rural development in Ukraine and to identify problems of their application by local governments. The authors proposed to improve the mechanism for financing rural development by active use its budgetary, credit and investment instruments. The prevalence of budgetary funding, whose limitation constrained rural development, was proven. Modern approaches to financing rural development were stated based on broadening community involvement in local budgeting, as well as in attracting investment resources.

It has been found out that government subventions are the most powerful support instrument for rural development in the spheres of infrastructure, education, health care etc. The possibilities of financing rural development through the development budgets under financial decentralization have been investigated. It was noted that the use of participatory budgeting and other forms of project finance most clearly demonstrated real democratic transformations in local finance in Ukraine. The proposals for the use of PPP agreements, crowdfunding, and international funds' grant programs for financing rural development were provided.
\end{abstract}

Key words: rural development, financing, local budgets, project budgeting, borrowings.

JEL code: H72, R51

\section{Introduction}

Rural development issues are relevant to most countries, as urban settlements typically make up only a small part of their territory. In Ukraine, rural areas occupy $90 \%$ of the country's territory, with almost a third of the country's population living there. They are territories with dominant agricultural activities which guarantee food security for the state and have considerable natural, economic, historical and cultural potential. Therefore, it is extremely important to enable conditions for their sustainable development, which, above all, includes sufficient and stable funding.

The problem of financing rural development has long been kept under review by scientists. However, some authors boil it down to lending or microfinancing to agricultural producers (Drabenstott and Morris, 1989; Shobande, 2018) or to the means of their government support (Abramova, 2018), which is a narrow approach. Bydyk (2013) and Storonianska and Pelekhatyi (2014) are much broader in identifying sources and methods of such funding, offering their own vision of conceptual approaches to the creation of the rural development financing mechanism. The point of view of those scholars who link the issues of rural development with the improvement of the functioning of territorial communities, the effectiveness of local governments (Kravchenko, 2015), the decentralization processes (Sutiyo and Maharjan, 2017; Dubnevych et al., 2019), and with the corresponding growing of budgetary and extra-budgetary resources and the use of new funding methods (Singh, 2009; Fock and Wong, 2008; Dorosh et al., 2019) is the most promising for us.

Therefore, the aim of the article is to systematize modern means of financing rural development in Ukraine and to identify problems of their application by local governments. The financial aspects of agricultural enterprises' and farming development along with their impact on rural development

\footnotetext{
${ }^{1}$ Svitlana Yehorycheva: e-mail: yehorycheva.sb@gmail.com

2Tetiana Hudz: e-mail: gtp9@ukr.net
}

3Mykola Lakhyzha: e-mail: lahisha@ukr.net 
are beyond the scope of the study. The tasks of the study are: to find out the possibilities of financing rural development at the expense of local budgets in the context of financial decentralization in Ukraine; to identify areas for public initiative in financing rural development; to propose the ways for more active use of lending and investment instruments. The research hypothesis is based on the awareness of the need to improve methods and implement innovative financing tools for rural development. The systematic analysis and comparative-legal methods were used to research the modernization of the mechanism for financing rural development. The structural-functional method was used to study budget financing technologies. Comparative analysis was applied to determine the national specificity of rural development financing. The mechanism for financing rural development has been further developed in the article by systematizing its budgetary, credit and investment instruments. This made it possible, firstly, to prove the prevalence of budgetary funding, whose limitation constrained rural development; secondly, to open up modern approaches to financing rural development based on broadening community involvement in local budget formation and use, as well as in attracting credit and investment resources.

\section{Research results and discussion}

Nowadays the Ukrainian agriculture is developing dynamically. In the period 2010-2018, agricultural production increased by $43.7 \%$; in 2018 agricultural, forestry and fishery production made up 10\% of GDP (State Statistics Service ..., 2020), and agricultural products formed more than $40 \%$ of the national exports of goods (National Bank of Ukraine, 2020). However, despite these positive economic results, the situation in rural areas in Ukraine is generally characterized by low quality of life, depopulation processes, mono-functional use of labour, large-scale labour migration, higher unemployment rate compared to urban settlements (8.6\% compared with $7.9 \%)$, the decay of social facilities, and the growing environmental challenges. As a result, the ability to meet the primary economic and social needs of the rural population is significantly narrowed, not to mention opportunities for personal development, complete recreation and other aspects of extended reproduction of labour potential. This situation is due to the fact that for a long time rural areas were considered only as a spatial basis for the development of agriculture. Asymmetry of regional development in Ukraine, not only at the regional level, but also between urban and rural territories can, over time, pose a real threat to national security.

Consequently, socio-economic development of rural areas in Ukraine requires modernization of its financial support mechanism. The modern elements of this mechanism can be represented as following (Figure 1).

\section{Budget methods of financing and their improvement}

Financial decentralization, which began in Ukraine in 2014-2015, was aimed at achieving selfsufficiency of territorial communities, their ability to meet both current demands and, most importantly, sustainable growth needs. The key areas of financial decentralization were: the expansion of the local budgets' own revenue base, first of all, the budgets of newly created amalgamated territorial communities (ATC), the implementation of a new budgetary regulation mechanism with new types of intergovernmental transfers, the decentralization of spending powers. Considering that among 8.2 thousand local budgets operating in early 2020 in Ukraine, 7.8 thousand budgets are related to rural territories (district, ATC, settlement, village), it is possible to conclude with a high level of certainty that the tendency of strengthening their financial capacity also means increasing resources for rural development. Over the past five years, the own revenues of the general 
fund of the local budgets have quadrupled and amounted to UAH 275.0 billion at the end of 2019 (Ministry of Finance ..., 2020).

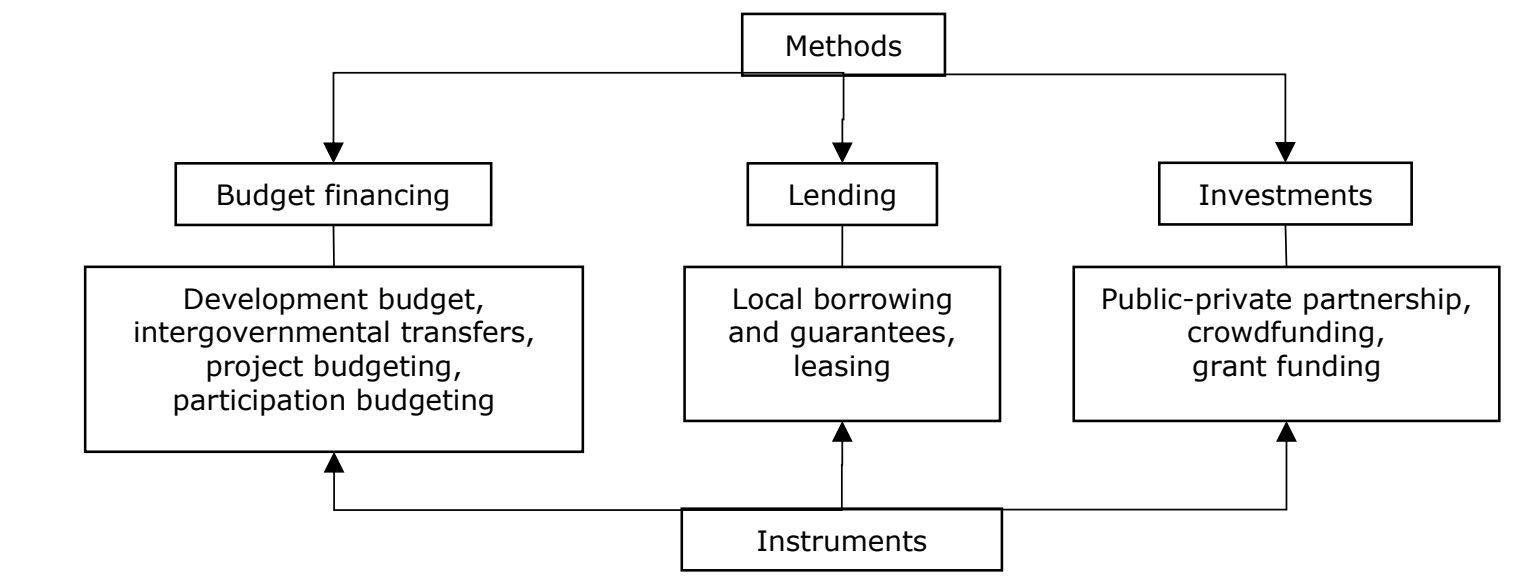

Source: author's scheme

Fig. 1. Methods and instruments for financing rural development in Ukraine

Along with the general growth of local budget revenues, their development budgets are also increasing. Their funds are channelled to expanded reproduction, investment projects, construction and reconstruction of the socio-cultural facilities and utilities, infrastructure development, environmental protection etc. (Pelekhata, 2013). In 2015-2017, the development budgets increased fivefold, representing more than a quarter of local budgets' revenues (Budgetary monitoring, 2017). However, the composition of development budget's sources has changed: instead of its own stable revenues, now it can be formed at the expense of the budget's general fund. This allows local governments to determine the size of the development budget on their own, but does not exclude subjectivity in decision-making. Therefore, it is advisable to return to the practice of transferring local taxes and fees to the development budget, as well as to consider the possibility of transfer the share of income tax of enterprises registered in the relevant territory to it.

The aim of the financial decentralization is not only to increase financial resources of local governments, but also to increase the efficiency of use of budgetary funds, channelling them in particular to the rural development. From this point of view, it is worth analysing the experience of project financing at the level of local budgets in Poltava region. Since 2010, the Poltava Regional Council has been holding a regional competition for territorial community development projects. Its participants are village councils, settlement and small town councils, district and city councils, and ATC. Since 2015, the projects of inter-municipal cooperation of territorial communities have also taken part in this competition. Public utilities, in particular, solid waste management, health care, education, fire protection, and road repair, etc. were the areas for their implementation.

During the period of competition 400 projects out of almost 800 ones submitted by local selfgovernment bodies to solve priority problems of sustainable local development have become winners. Over UAH 87.0 million has been assigned for their financing from the regional development budget, including UAH 46.4 million only in the last two years due to the significant increase in the number of submitted projects (Poltava Regional Council, 2020). Participation of local self-government bodies (not less than $50 \%$ of the project cost), as well as involvement of partner NGOs in financing are a prerequisite for submitting projects. The funds of the project of German Society for International Cooperation (GIZ) "Management Reform in the East of Ukraine" are also actively used for the implementation of projects. So, the regional competition contributes to the support of local initiatives 
and the application of project approaches to the local budget spending, which increases their efficiency and effectiveness. The vast majority of projects are implemented in rural areas: for instance, in 2020, 40 projects out of 49 projects-winners will be carried out in villages or ATC.

The mechanism for financing rural development is now being transformed through the implementation of the concept of participatory budgeting. Global practice shows that development projects based on the direct involvement of the local inhabitants and aimed at meeting their needs are geared local priorities. Transparent allocations of budgetary resources, more complete satisfaction of the needs for public services, increase in efficiency of local self-governments are the results of such budgeting. The idea of participatory budgeting came to Ukraine in 2015, and it began to be implemented primarily in cities. Later on, some rural ATCs joined the process. In the beginning of 2020 more than thirty rural ATCs have joined the web service "Public Budget. E-democracy Platform" to post relevant information and vote online for development projects (Public Budget. E-democracy ..., 2020).

However, participatory budgeting can be extended to the regional level, as evidenced by the experience of the Poltava region. In 2017, the Poltava Regional Council launched the first in Ukraine and even in Europe program "Participatory Budget" extended to the whole region which was a leading one in the sphere of agriculture (Poltava Regional Council, 2020). Initially, UAH 6.354 million was envisaged from the regional budget for the implementation of the program for four years, but the amount was increased by three times in the last two years to a total of UAH 14.7 million (Table 1). The maximum cost of one project is UAH 100.0 thousand; funding is provided on a parity basis (50/50) with the relevant local council. The geography of projects is constantly expanding. In 2018, the winners (60 projects) represented 15 districts of Poltava region; in 2019 the winners (71 projects) represented 17 districts.

Table 1

Implementation indicators of the regional program "Participatory Budget of Poltava Region for 2017-2020"

\begin{tabular}{|l|c|c|c|c|c|}
\hline \multicolumn{1}{|c|}{ Indicators } & $\mathbf{2 0 1 7}$ & $\mathbf{2 0 1 8}$ & $\mathbf{2 0 1 9}$ & $\mathbf{2 0 2 0}$ & Total \\
\hline $\begin{array}{l}\text { Estimated amount of funds from the regional budget, } \\
\text { thousand UAH }\end{array}$ & 135 & 2068 & 2073 & 2078 & 6354 \\
\hline $\begin{array}{l}\text { Actual amount of funds from the regional budget, thousand } \\
\text { UAH }\end{array}$ & 135 & 2190 & 6190 & 6190 & 14705 \\
\hline Number of projects to vote & 189 & 260 & 200 & $\ldots$ & 649 \\
\hline Number of winning projects & 42 & 60 & 71 & $\ldots$ & 173 \\
\hline
\end{tabular}

Source: author's calculations based on (Poltava Regional Council, 2020)

The improvement of participatory budgeting in the Poltava region continues. In 2019, the Poltava Regional Council initiated a school-based participatory budgeting. It is implemented within the program "Participatory Budget of Poltava Region for 2017-2020"; its total amount is UAH 1.0 million (up to 50.0 thousand UAH for each project). In 2019, 160 projects aimed at the development of education in the Poltava region, in particular, the implementation of the concept of the New Ukrainian School, were submitted. Almost $80 \%$ of the projects were submitted by the schoolchildren from the villages and settlements so they aimed to solve the education problems in rural areas.

At the same time, it is clear that only at the expense of the own funds of the local budgets it is impossible to solve complex socio-economic problems of rural development. So, subventions from the state budget became one of the important instruments of its financing. Over the five years, the amount of local development subventions has increased by almost 55 times (Table 2). The main 
condition for obtaining a subvention for socio-economic development is its use to create, increase or update the communal capital assets if the already approved construction projects are available.

Table 2

\section{Dynamics of government subsidies provided to local budgets for development purposes, UAH billion}

\begin{tabular}{|l|c|c|c|c|c|c|}
\hline \multicolumn{1}{|c|}{ Name of Subvention } & $\mathbf{2 0 1 4}$ & $\mathbf{2 0 1 5}$ & $\mathbf{2 0 1 6}$ & $\mathbf{2 0 1 7}$ & $\mathbf{2 0 1 8}$ & $\mathbf{2 0 1 9}$ \\
\hline $\begin{array}{l}\text { Subvention for socio-economic development of } \\
\text { certain territories }\end{array}$ & 0,5 & 0,8 & 3.3 & 6.2 & 5,0 & 4.7 \\
\hline Subvention for the formation of ATC infrastructure & - & - & 1.0 & 1.5 & 1.9 & 2.1 \\
\hline $\begin{array}{l}\text { Subvention for the development of medicine in } \\
\text { rural areas }\end{array}$ & - & - & - & 4.0 & 5.0 & 5.0 \\
\hline Subvention for the construction of sports facilities & - & - & - & 0.27 & 0.37 & 0.75 \\
\hline $\begin{array}{l}\text { Subvention for construction, reconstruction, repair } \\
\text { and maintenance of public roads of local } \\
\text { importance }\end{array}$ & - & - & - & - & 11.5 & 14.7 \\
\hline
\end{tabular}

However, experts estimate that there is no clear relationship between the level of development of the region, the total amount of subventions allocated and the amount of subvention per capita. In general, the distribution of such a subvention is disproportionate. The subvention for the formation of ATC infrastructure is distributed in proportion to the territory and the number of rural population in the ATC, with equal weights of both factors. This subvention is characterized by the objectivity and uniformity of its distribution, as well as a high level of funds' spending (almost $98 \%$ in 2018). Except for project financing this subvention can be used to improve the quality of administrative services, to create modern management systems, to purchase vehicles, etc. Subvention for the development of medicine can be spent on new construction and reconstruction, purchase of medical equipment, development of telecommunication infrastructure of healthcare institutions.

The funds received by local budgets from the State Regional Development Fund, which is formed as part of the state budget, are one more source of project financing for rural development in terms of financial decentralization. The projects submitted by the local executive authorities and local self-governments must comply with one of three areas - strategic plans for the regional development, support for voluntary amalgamation of territorial communities and projects for cooperation of territorial communities. In recent years, the amount of these competitively allocated to local budgets funds has increased from UAH 2.9 billion in 2015 to UAH 7.67 billion in 2019 that is more than 2.5 times. Each year, the government approves funding for about 400 local development projects. But attention is constantly paid to the poor quality of the projects submitted for competition. It is important to develop and implement projects that have a multiplier effect, stimulate spatial development, create jobs, generate added value and be a source of future budget revenue (Decentralization, 2018).

\section{Credit and investment instruments of rural development financing}

Speaking about credit instruments of the mechanism for financing rural development we have to mention local borrowing which local governments are entitled to in accordance with the Budget Code of Ukraine. Also, they have the right to give guarantees to local enterprises. Local borrowing' funds are channelled into the development budget. In 2017-2019, about 70 local borrowings were made in Ukraine, mainly in the form of loans from international financial institutions and domestic banks (Ministry of Finance of Ukraine, 2020). However, only the city councils were the borrowers, their relevant right is clearly enshrined in Art. 16 of the Budget Code. With regard to ATCs, which have got broad budgetary powers through financial decentralization, the possibility of borrowing and 
providing guarantees is stated only indirectly in Art.67 "Some features of local budgeting" (Budget Code of Ukraine, 2020). Thus, the lack of interest of ATC in attracting additional funds to the development budget through local borrowing is due not so much to economic feasibility as to legal uncertainty that impedes rural development financing.

Leasing, whose market is actively developing in Ukraine, is gradually becoming a powerful funding source for the economic development of rural areas. In 2016-2018, the total value of leasing agreements increased from UAH 9.8 billion to UAH 22.2 billion, with the main lessees being agricultural enterprises (National Commission for the State ..., 2020). Recently, the municipal enterprises have been entering the leasing market with the financial support of their founders - local governments, who are worried about renewing the fleet and equipment for the public utilities. However, we can't so far report about any decision taken by the ATC council to authorize a leasing contract for the company in which it is the founder, with the corresponding guarantee to the creditor. The reason is, on the one hand, in the aforementioned legislative uncertainty, and on the other hand, in the complexity and duration of the procedure of changing the legal status of municipal enterprises belonging to different local councils in the process of forming an ATC.

With budget constraints, local governments can also address rural development through the use of public-private partnership (PPP), which is a complex mechanism for combining efforts of public and private entities to optimize the creating and using infrastructure and public services provision. In Ukraine, the Law on Public-Private Partnership and the Law on Concession have created a sufficient legal framework for implementing the PPP, but this mechanism has not become widespread. At the beginning of 2020, 187 contracts have been concluded, of which only 52 contracts are being implemented (34 - concession contracts, 16 - joint activity contracts, 2 - other contracts), 135 contracts are not being implemented (among them 4 contracts expired, 18 contracts were terminated) (Ministry for Development of Economy ..., 2020). As a rule, the issues of local development - water supply and sanitation, alternative energy, household waste management etc. are the subjects of the PPP agreements. Village councils are also among public partners. However, according to experts, the spread of PPP practices in Ukraine is constrained by both general economic problems and the weak awareness of territorial communities' management about PPP mechanisms, and the lack of relevant specialists.

Crowdfunding can be considered an innovative tool for financing rural development. Today, many web platforms are already operating in Ukraine to raise funds for different needs, so network crowdfunding technologies can be used to finance small rural development projects too. This technology greatly simplifies the fundraising process, with real "targeting" of resources. There are the first examples of the usage of such a financial instrument already: in 2017 - the "Kinderland" project of the Oleksiivka school of Zaporizhzhya region; in 2018, the schoolchildren of the Berezovka ATC of Odessa region raised funds for the roller rink's arrangement; NGO "Youth chooses life" raised funds for the implementation of the project "Creating an Art Space in the Village of Ivankivtsi" in Zhytomyr region; in 2019, the Chopovichy ATC in Zhytomyr region funded the project of creating a Youth Centre in the premises of a local cultural centre (Decentralization, 2020). At the same time, it is clear that in the face of social infrastructure decline, crowdfunding can't be the preferred method in solving social problems in rural areas. 


\section{Conclusions, proposals, recommendations}

1) The article presents the author's vision of systemizing modern means for financing rural development, as opposed to the mechanism of state support for the agricultural sector.

2) The analysis of the mechanism of financing rural development in Ukraine has confirmed the existence of significant discrepancies between theory and practice. This is evidenced, in particular, by the internal contradiction of the "Concept of Rural Development" (2015), where the following problems are identified: the unwillingness of territorial communities to initiate and participate projects; low efficiency of local self-government bodies; limited local budget resources to address rural development issues; low level of financial support of rural areas. However, activities specified in the document do not provide for their solution.

3) The possibilities of financing rural development at the expense of local budgets in the context of financial decentralization are found out by the example of Poltava region. The deepening of the decentralization process in Ukraine opens additional opportunities for increasing the financial capacity of territorial communities. The practice of the Poltava region illustrates the desire of local self-government bodies to use modern methods of financing rural development in accordance with present requirements. The experience of implementing from 2017 the participation budgeting program at the regional level is unique both in Ukraine and in Europe and can be recommended for active use in all regions of the country.

4) The areas for public initiative in financing rural development have been identified. The citizens' initiative arises within the framework of collaborative governance, which is to build a consensus between the rural community and local governments to improve public service delivery in such areas as infrastructure, health, education, communications, landscaping etc. Initiation and implementation of a budget public initiative depends on the intensity of the decentralization processes, the degree of public maturity and self-awareness of citizens, the level of Internet technologies' mastering.

5) The possibilities for more active use of lending and investment instruments are proposed. It is established that during the transitional period, and possibly for a longer time, a complex approach is needed - combining government subventions to regions with the enhance of their own financial capacity. It is necessary to activate the territorial community to find alternative sources of funding, to cooperate with international funds, programs, to receive grants etc. At the same time, the development of public-private partnership, a promising form of which for regional development is a concession, should be encouraged. Crowdfunding also becomes an innovative tool for financing rural development.

\section{Bibliography}

1. Abramova, I. (2018). Status and Prospects of Financial Support for Rural Development. Scientific Horizons, 5(68), pp. 44-52.

2. Budgetary monitoring. Institute of Budget and Socio-Economic Research (2017). Retrieved: https://www.ibser.org.ua/publications/monitoringcategories/shchomisyachnyy. Access: 16.01.2020.

3. Budget Code of Ukraine (2020). Retrieved: https://zakon.rada.gov.ua/laws/show/2456-17. Access: 20.01.2020.

4. Bydyk, A. (2013). Theoretical Structure of the Financial Mechanism Providing the Development of Rural Areas. Innovative Economy, 3(41), pp. 156-162.

5. Concept of Rural Development : Decree of the Cabinet of Ministers of Ukraine No. 995-r of September 23, 2015. Retrieved: https://zakon.rada.gov.ua/laws/show/995-2015-\%D1\%80. Access: 28.02.2020.

6. Decentralization (2018). Retrieved: https://decentralization.gov.ua/. Access: 25.02.2020.

7. Dorosh, O., Dorosh, I., Fomenko, V., Dorosh, A., Saliuta, V. (2019). Assessment of the System of Allocation of Subventions and Subsidies and Their Impact on the Development of Rural Territories. Scientific Papers 
Series Management, Economic Engineering in Agriculture and Rural Development, Volume 19, Issue 1, pp. 161-168.

8. Drabenstott, M., Morris, Ch. (1989). New Sources of Financing for Rural Development. American Journal of Agricultural Economics, Volume 71, No. 5, pp. 1315-1323.

9. Dubnevych Yu., Dubnevych N., Dorosh U. (2019). Social and Economic Development of Rural Areas under Conditions of Decentralization. Agricultural economics, Volume 10, Issue 1-2, pp. 24-31.

10. Fock, A., Wong, C. (2008). Financing Rural Development for a Harmonious Society in China: Recent Reforms in Public Finance and Their Prospects. World Bank Policy Research Working Paper 4693. 67 p. Retrieved: https://papers.ssrn.com/sol3/papers.cfm?abstract_id=1233069. Access: 15.02.2020.

11. Kravchenko, T. (2015). Rural Development Based on Communities: Innovation of Public Policy in Ukraine. Actual Problems of Public Administration, 1(47), pp. 87-94.

12. Ministry for Development of Economy, Trade and Agriculture of Ukraine (2020). Retrieved: https://www.me.gov.ua/Tags/DocumentsByTag?lang=uk-UA\&id=cffc9f41-f2ef-45e6-8303Of8fc0e368f0\&tag=Derzhavno-privatnePartnerstvo. Access: 06.02.2020.

13. Ministry of Finance of Ukraine (2020). Retrieved: https://mof.gov.ua/uk/miscevij-borg-ta-miscevijgarantovanij-borg-osn-inf. Access: 03.02.2020.

14. National Bank of Ukraine. Retrieved: https://bank.gov.ua/statistic/sector-external/data-sector-external\#1. Access: 28.01.2020.

15. National Commission for the State Regulation of Financial Services Markets (2020). Retrieved: https://www.nfp.gov.ua/ua/Ohliad-rynkiv.html. Access: 05.02.2020.

16. Poltava Regional Council (2020). Retrieved: https://oblrada-pl.gov.ua/. Access: 31.01.2020.

17. Pelekhata, O.V. (2013). Budget of Development as a Tool of Rural Territorial Community in the Process of Implementation of Fiscal Policy for Economic Growth. Socio-economic Problems of the Modern Period of Ukraine, 6(104), pp. 355-361.

18. Public Budget. E-democracy Platform (2020). Retrieved: https://budget.e-dem.in.ua/\#/. Access: 31.01.2020.

19. Shobande, O. (2018). Rural Financing for Economic Development in Africa: Context and Reality. Annals of the University of Craiova: Economic Sciences Series, 1, pp. 39-43.

20. Singh, K. (2009). Financing Rural Development (Rural Development: Principles, Policies and Management). SAGE Publications India Pvt Ltd, pp. 283-308.

21. State Statistics Service of Ukraine (2020). Retrieved: http://www.ukrstat.gov.ua/. Access: 17.02.2020.

22. State Treasury Service of Ukraine (2020). Retrieved: https://www.treasury.gov.ua/ua. Access: 11.01.2020.

23.Storonianska, I., Pelekhatyi, A. (2014). Ways of Modernization of Financial Support for Territorial Communities' Development through Tasks of Administrative-Territorial Reform. Finance of Ukraine, 10, pp. 97-108.

24.Sutiyo, Maharjan, K. L. (2017). Decentralization and Rural Development in Indonesia. Springer Nature Singapore Pte Ltd. 162 p. 